\title{
Evaluation of the Effects of Intra and Inter Row Spacing on the Growth and Yield of Ground Nut (Arachis Hypogaea L.) at Haro Sabu, Western Ethiopia
}

\author{
Teshome Gutu*, Dereje Abera and Biru Alemu \\ Oromia Agricultural Research Institute, Haro Sebu Agriculture research center
}

\begin{abstract}
Ground nut (hypogaea L.) is one of most important food crop grown in Oromia Regional State, Ethiopia. However, its productivity is very low due to inappropriate intra and inter spacing practice. Thus, the study was conducted in 2016 and 2017 during the main cropping season at Haro Sabu Agricultural Research Center and Kombo subsite of Kelem Wollega zone of Western Ethiopia to identify the effects of different spacing on growth parameters, yield and yield components of ground nut varieties. The experiment was laid out in Randomized complete Block design with three replications in factorial arrangement. The experiments was consist of two factors. Nine levels of spacing were $50 \mathrm{~cm} \times 5 \mathrm{~cm}, 50 \mathrm{~cm} \times 10 \mathrm{~cm}, 50 \mathrm{~cm} \times 15 \mathrm{~cm}, 60 \mathrm{~cm} \times 5 \mathrm{~cm}, 60 \mathrm{~cm} \times 10 \mathrm{~cm}$, $60 \mathrm{~cm} \times 15 \mathrm{~cm} 75 \mathrm{~cm} \times 5 \mathrm{~cm}, 75 \mathrm{~cm} \times 10 \mathrm{~cm}, 75 \mathrm{~cm} \times 15 \mathrm{~cm}$ and two varieties (Manipinter and Sartu). The highest total number of pods per plant (21.36) was obtained from variety manipinter. Regarding to spacing, the highest number of pods per plant (25.00) was obtained from $75 \mathrm{~cm} \times 10 \mathrm{~cm}$ and followed by $75 \mathrm{~cm} \times 15 \mathrm{~cm}(22.45)$. The highest hundred seed $(66.85 \mathrm{~g})$ weight and grain yield $\left(2105 \mathrm{~kg} \mathrm{ha}^{-1}\right)$ was recorded from manipinter variety. Regarding to spacing, the highest grain yield $\left(2474\right.$ and $\left.2433 \mathrm{~kg} \mathrm{ha}^{-1}\right)$ was obtained from $50 \mathrm{cmx} 5 \mathrm{~cm}$ and $60 \mathrm{~cm}$ $\mathrm{x} 5 \mathrm{~cm}$ respectively. The highest net benefit $\left(50269.00\right.$ and $\left.50245.00 \mathrm{ETB} \mathrm{ha}^{-1}\right)$ was recorded from $50 \mathrm{~cm} \times 5 \mathrm{~cm}$ and $60 \mathrm{~cm} \times 5 \mathrm{~cm}$ spacing respectively. However the highest marginal rate return $(288.46 \%)$ was recorded from spacing $60 \mathrm{~cm} \times 5 \mathrm{~cm}$ followed by $50 \mathrm{~cm} \times 5 \mathrm{~cm}(2.66 \%)$. Therefor spacing of $50 \mathrm{~cm} \times 5 \mathrm{~cm}$ and $60 \mathrm{~cm} \times 5 \mathrm{~cm}$ was optimum plant population density for production of ground nut in Kelem Wollega zone of western Ethiopia.
\end{abstract}

Keywords: Arachis hypogaea L., grin yield, interaction effect, spacing

DOI: $10.7176 / \mathrm{ALST} / 70-04$

\section{INTRODUCTION}

Groundnut (Arachis hypogaea L.) is an important monoecious annual legume used for oilseed, food and animal feed (Pande et al., 2003; Upadhyaya et al., 2006). It is the main source of food in various forms and used as a component of crop rotation in many countries (Gbèhounou and Adengo, 2003). Groundnut is grown on 26.4 million ha worldwide with a total production of 38.2 million metric tons (FAOSTAT, 2010). Developing countries account for $97 \%$ of the world's groundnut area and $94 \%$ of the total production.

The lowland areas of Ethiopia have considerable potential for increased oil crop production including groundnut. The estimated production area and yield of groundnut in Ethiopia in 2016/2017 cropping season were 74861.37 hectares and 1296364.18 quintals, respectively (CSA, 2017). The seed yield is a function of interaction between genetic and environmental factors including soil type, sowing time and method, seed rate, fertilizers and time of irrigation among which, row spacing plays a vital role in getting higher yield (Hussain et al., 2003). Proper spacing ensures adequate ventilation, reduces competition among plants for space and nutrients, and reduces transmission of diseases, facilitates weeding and movement in the farm and also reduces overcrowding and, therefore; allows interception of radiation by plant canopies.

The response of ground nut to plant density has been investigated in many areas of the world. Investigation of growth and yield performance of ground nut with special reference to arrangement has been conducted and the result showed that leaf area index, crop growth rate, pod growth rate, pod and kernel yield have increased by increasing plant density (Kiniry et al., 2005). Cultivation of groundnut in narrow rows can lead to maintenance of a complete crop cover over the soil which inhibits weed seed germination and reduces the need to carry out weeding (Lee et al., 1994). Early canopy closure by closely spaced groundnut crop has been shown to smother weeds hence reducing weed/crop competition, especially for soil nutrients and water. Such benefits are more evident under low input conditions as seen on most smallholder farms.

Some investigators concluded that narrow row spacing was superior in yield and more economical than broader rows (Pereira et al., 1988). Plants growing in too wide rows may not efficiently utilize the natural resources such as water and nutrients, whereas growing in too narrow rows may result in sever inter and intrarow spacing competition (Ali et al.,1999). Therefore, it is of crucially important to manipulate the row spacing in order to increase plant productivity. Production of groundnut is under progress since recently in west and Kellem Wollega zones. The information of agronomic practices such as row and planting spacing is limited because it is produced at subsistence level by rural farmers and the farmer cultivate ground nut without consideration of the appropriate row and plant spacing. Research on manipulating plant density and their effects on growth and yield 
are crucial so as to generate enough information and data base for use by emerging farmers that would be interested in commercial production of this crop. Thus, the present investigation was aimed to determine the effects of row and plant spacing on growth parameters, yield and yield component of ground nut varieties.

\section{MATERIALS AND METHODS}

\section{Description of the Study Area}

The experiment was conducted at Haro Sabu Agricultural Research Center (HARC) and Kombo subsite during 2016 and 2017 the main cropping season. HARC and kombo were located in kellem wollega zone, western Ethiopia at 550 and $580 \mathrm{~km}$ away from Addis Ababa and $1530 \mathrm{~m}$ above sea level.The area receives average annual rain fall of $1000 \mathrm{~mm}$ and its distribution pattern is uni-modal. The rain periods covers from April to October at both site. The soil type of the experimental site was reddish brown and its $\mathrm{pH}$ is 5.82 . The area is characterized by crop livestock mixed farming system in which cultivation of maize, sorghum, finger millet, haricot bean, soybean, sesame, ground nut, coffee, banana, mango, sweet potato and coffee are the major crops grown in the area.

\section{Treatments and Experimental Design}

The experiment was consist of two factors. Nine levels of spacing were $50 \mathrm{cmx} 5 \mathrm{~cm}\left(400,000 \mathrm{plants}^{-1}\right)$, $50 \mathrm{~cm} \times 10 \mathrm{~cm} \quad\left(200,000\right.$ plants $\left.\mathrm{ha}^{-1}\right), \quad 50 \mathrm{~cm} \times 15 \mathrm{~cm} \quad\left(133,333\right.$ plants ha $\left.\mathrm{ha}^{-1}\right), \quad 60 \mathrm{~cm} \times 5 \mathrm{~cm} \quad\left(333,333 \mathrm{plants}^{-1}\right.$ ha ${ }^{-1}$, $60 \mathrm{~cm} \times 10 \mathrm{~cm} \quad\left(166,670\right.$ plants $\left.\mathrm{ha}^{-1}\right), 60 \mathrm{~cm} \times 15 \mathrm{~cm} \quad\left(111,113\right.$ plants ha $\left.\mathrm{ha}^{-1}\right), \quad 75 \mathrm{~cm} \times 5 \mathrm{~cm} \quad\left(266,666 \mathrm{plants}^{-1}\right.$ ha $\left.{ }^{-1}\right)$, $75 \mathrm{~cm} \times 10 \mathrm{~cm}\left(133,330\right.$ plants ha $\left.{ }^{-1}\right), 75 \mathrm{~cm} \times 15 \mathrm{~cm}\left(88,887\right.$ plant ha $\left.^{-1}\right)$ and two varieties (Manipinter and Sartu). The experiment was laid out in Randomized complete Block design with three replications in factorial arrangement. The gross plot area was $3 \mathrm{mx} 3.9 \mathrm{~m}=11.7 \mathrm{~m}^{2}$ and Four, five and six rows were planted depending on the row spacing in each plot

\section{Experimental Procedures}

The experimental field was ploughed and harrowed by a tractor to get a fine seedbed and leveled manually before the field layout was made. Two seeds per hill were planted and thinned to one plant per hill one week after emergence. At planting full dose of DAP $\left(18 \% \mathrm{~N}, 46 \% \mathrm{P}_{2} \mathrm{O}_{5}\right)$ at the rate of $100 \mathrm{~kg} \mathrm{ha}^{-1}$ was applied uniformly into all plots. It was harvested from the net plot after they attained their normal physiological maturity.

\section{Data Collection}

Data were collected on: Days to flower initiation, Days to physiological maturity, Number of primary branches, Plant height $(\mathrm{cm})$, Number of pods plant ${ }^{-1}$, Number of seeds pod ${ }^{-1}$, Hundred grain weight $(\mathrm{g})$ and Grain yield $(\mathrm{kg}$ $\mathrm{ha}^{-1}$ ) were recorded. Days to flower initiation was recorded as the number of days from planting to the time when $50 \%$ of the plants produced at least one flower. Days to physiological maturity was recorded as the number of days from planting to the time when $95 \%$ of pods reached maturity. Number of primary branches was determined by taking five randomly selected plants per plot at harvesting time. Plant height was measured from the base of plant to the tip of the main stem at the stage of physiological maturity. Number of pods was determined by counting total number of pods from five randomly selected plants from each net plot at the time of harvesting. Number of seeds per pod was determined by counting total seeds of counted pods from five randomly selected plants and divided by the total number of pods. Hundred grain whight was recorded by weighted hunderde seed. Grain yield was recorded by weighted of harvested grain yield from each net plot

Data Analysis

Analysis of variance was carried using General Linear Model of ANOVA using SAS version 9.1 software (SAS, 2002). Mean separation was carried out using Least Significance Difference (LSD) test at 5\% probability level.

\section{Economic analysis}

The partial budget analysis as described by CIMMYT (1988) was done to determine the economic feasibility of row and plant spacing practices. Economic analysis was done using the prevailing market prices for inputs at planting and for output at the time of crop harvest. It was calculated by taking into account the additional input and labour cost involved and the gross benefits obtained from row and plant spacing practices. The field price of $1 \mathrm{~kg}$ of groundnut that farmers receive from sale for the crop was taken as 25 Birr based on the market price of groundnut at Harosebu near the experimental site. The average yield was adjusted downward by $10 \%$ to reflect the difference between the experimental yield and the yield farmers could expect from the same weed management practices as described by CIMMYT (1988). The field price of groundnut was calculated as sale price minus the costs of harvesting, threshing, winnowing, bagging and transportation. The total cost that varied included the sum of cost of seed and labour cost management practice is required. The net benefit was calculated as the difference between the gross field benefit (Ethiopian birr ha ${ }^{-1}$ ) and the total costs (Ethiopian birr ha-1) that varied.

\section{RESULTS AND DISCUSSION}

The analysis of variance revealed that days to $50 \%$ flower initiation and days to physiological maturity were highly significantly $(\mathrm{P} \leq 0.01)$ affected by varieties. Varieties 'Manipinter' reached to $50 \%$ flower initiation on 
Grain yield was highly significantly $(\mathrm{P} \leq 0.01)$ affected by main effect of variety and spacing. Whereas, the interaction effect of variety and spacing was non-significant effect on grin yield. The highest grain yield (2105 $\left.\mathrm{kg} \mathrm{ha}^{-1}\right)$ was obtained from variety mainipinter while the lowest grain yield $\left(1373 \mathrm{~kg} \mathrm{ha}^{-1}\right)$ was obtained from variety 'sartu' (Table 2). The highest grain yield produced by variety 'mainipintar' could be attributed to its more hundred seed weight. The variations in grain yield of varieties was probably attributable to genetic differences between varieties. Similar findings have been reported by earlier studies (Abdullah et al., 2007; Virender and Kandhola, 2007). Regarding to spacing, the highest grain yield (2474 and $2433 \mathrm{~kg} \mathrm{ha}^{-1}$ ) was obtained from $50 \mathrm{~cm} \times 5 \mathrm{~cm}$ and $60 \mathrm{~cm} \times 5 \mathrm{~cm}$, respectively (Table 2). The grain yield at the higher plant densities might be due to efficient utilization of growth resources and the lowest grain yield at the lowest plant density might be attributed to the more luxurious growth because of the more resources at the lower plant density initiated more pod thickness than the grain yield. In line with this result, Bihter O. et al. (2017) found that Pod yield per hectare was increased when the plant density was increased; the highest pod yield $\left(7511.9 \mathrm{~kg} \mathrm{ha}^{-1}\right) \mathrm{was}^{2}$ obtained from $75 \mathrm{~cm} \times 10 \mathrm{~cm}$ and the lowest $\left(5171 \mathrm{~kg} \mathrm{ha}^{-1}\right)$ was from $75 \mathrm{~cm} \times 25 \mathrm{~cm}$ planting density. Also Naeem et,al. (2007) reported that significant variation was observed on pod yield due to row spacing; the highest (3739 $\left.\mathrm{kg} \mathrm{ha}^{-1}\right)$ and the lowest $\left(1903 \mathrm{~kg} \mathrm{ha}^{-1}\right)$ pod yield was recorded from $30 \mathrm{~cm}$ and $60 \mathrm{~cm}$ row spacing respectively. Generally, decrease in spacing reduced the number of pods per plant but the additional plants $\mathrm{m}^{-2}$ more than compensated for the reduction, resulting in higher pod yield. Such compensation effects have been reported by Ahmad et al. (2007), Norden and Lipscomb (1974). Thus spacing arrangement that resulted in high plant population density was more efficient in the use of solar energy and other resources for pod production (Virk et al., 2005).

Table 2: Main effects of varieties and spacing on yield and yield component during 2016 and 2017 growing season of both location

\begin{tabular}{|c|c|c|c|c|}
\hline Treatment & NPPP & NSPP & HGW & $\mathrm{GY}\left(\mathrm{kg} \mathrm{ha}^{-1}\right)$ \\
\hline \multicolumn{5}{|l|}{ Variety } \\
\hline Sartu & $19.33^{\mathrm{b}}$ & $1.70^{\mathrm{a}}$ & $41.27^{\mathrm{b}}$ & $1373^{\mathrm{b}}$ \\
\hline Manipinter & $21.96^{\mathrm{a}}$ & $1.51^{\mathrm{b}}$ & $66.85^{\mathrm{a}}$ & $2105^{\mathrm{a}}$ \\
\hline $\operatorname{LSD}_{(0.05)}$ & 1.32 & 0.07 & 2.37 & 116 \\
\hline \multicolumn{5}{|l|}{ Spacing } \\
\hline $50 \mathrm{~cm} \times 5 \mathrm{~cm}(400,000 \mathrm{pl} / \mathrm{ha})$ & $18.25^{\mathrm{c}}$ & 1.52 & 55.34 & $2474^{\mathrm{a}}$ \\
\hline $50 \mathrm{~cm} \times 10 \mathrm{~cm}(200,000 \mathrm{pl} / \mathrm{ha})$ & $20.03^{\mathrm{bc}}$ & 1.59 & 55.46 & $2140^{\mathrm{b}}$ \\
\hline $50 \mathrm{~cm} \times 15 \mathrm{~cm}(133,333 \mathrm{pl} / \mathrm{ha})$ & $19.60^{c}$ & 1.63 & 53.79 & $1323^{c}$ \\
\hline $60 \mathrm{~cm} \times 5 \mathrm{~cm}(333,333 \mathrm{pl} / \mathrm{ha})$ & $18.73^{c}$ & 1.7 & 53.02 & $2433^{\mathrm{a}}$ \\
\hline $60 \mathrm{~cm} \times 10 \mathrm{~cm}(166,670 \mathrm{pl} / \mathrm{ha})$ & $20.88^{\mathrm{bc}}$ & 1.61 & 55.28 & $1918^{\mathrm{b}}$ \\
\hline $60 \times 15 \mathrm{~cm}(111,113 \mathrm{pl} / \mathrm{ha})$ & $20.81^{b c}$ & 1.72 & 53.53 & $1260^{c}$ \\
\hline $75 \mathrm{~cm} \times 5 \mathrm{~cm}(266,666 \mathrm{pl} / \mathrm{ha})$ & $20.07^{\mathrm{bc}}$ & 1.51 & 55.37 & $1895^{\mathrm{b}}$ \\
\hline $75 \mathrm{~cm} \times 10 \mathrm{~cm}(133,330 \mathrm{pl} / \mathrm{ha})$ & $25.00^{\mathrm{a}}$ & 1.59 & 52.98 & $1258^{\mathrm{c}}$ \\
\hline $75 \mathrm{~cm} \times 15 \mathrm{~cm}(88,887 \mathrm{pl} / \mathrm{ha})$ & $22.45^{\mathrm{ab}}$ & 1.61 & 51.78 & $951^{\mathrm{d}}$ \\
\hline $\operatorname{LSD}_{(0.05)}$ & 2.81 & NS & NS & 245.65 \\
\hline $\mathrm{CV}(\%)$ & 23.90 & 17.05 & 16.37 & 24.80 \\
\hline
\end{tabular}

Means within the same column followed by the same letter or by no letters of each factor do not differ significantly at $5 \%$ probability level; LSD $=$ Least Significant Difference $(\mathrm{P}<0.05)$; CV=Coefficient of Variation; $\mathrm{NS}=$ Non Significant; NPPP=Number of pod per plant; NSPP=Number of seed per pod; $\mathrm{HGW}=\mathrm{Hundred}$ grain weight; $\mathrm{GY}=$ Grain yield

The economic analysis results for intra and inter row spacing are indicated in Tables 3 . The highest net benefit of ETB $50269 \mathrm{ha}^{-1}$ and marginal rate return of $2.6 \%$ was obtained from $50 \mathrm{~cm} \times 5 \mathrm{~cm}$ spacing for groundnut production followed by net benefit of ETB $50245 \mathrm{ha}^{-1}$ and marginal rate return of $288.46 \%$ from $60 \mathrm{~cm} \times 5 \mathrm{~cm}$ spacing (Table 3). However; the highest marginal rate return (2874.14\%) was recorded from spacing $60 \mathrm{~cm} \times 10 \mathrm{~cm}$ followed by $60 \mathrm{~cm} \times 15 \mathrm{~cm}(2213.7 \%)$. Thus, practicing of $50 \mathrm{~cm} \times 5 \mathrm{~cm}$ and $60 \mathrm{~cm} \times 5 \mathrm{~cm}$ spacing resulted in $18.6 \%$ increment to the groundnut income from that of $60 \mathrm{~cm} \times 10 \mathrm{~cm}$ spacing paractice. Thus, $50 \mathrm{~cm} \times 5 \mathrm{~cm}$ and $60 \mathrm{~cm} \times 5 \mathrm{~cm}$ is economically feasible for groundnut production in study area. 
Table 3. Effects of intra and inter row spacing on economic feasibility of groundnut production

\begin{tabular}{|c|c|c|c|c|c|c|c|}
\hline Treatment & $\begin{array}{c}\text { Yield (kg } \\
\text { ha-1) }\end{array}$ & $\begin{array}{c}\text { Adj } \\
\text { yield } \\
\left(\mathrm{kg} \mathrm{ha}^{-1}\right)\end{array}$ & $\begin{array}{c}\text { Price ETB } \\
\mathrm{kg}^{-1}\end{array}$ & $\begin{array}{c}\text { Revenue } \\
\text { (ETB ha-1) }\end{array}$ & $\begin{array}{l}\text { Marginal cost } \\
\left(\mathrm{ETB} \mathrm{ha}^{-1}\right)\end{array}$ & $\begin{array}{l}\text { Net profit } \\
\text { (ETB) }\end{array}$ & $\operatorname{MRR}(\%)$ \\
\hline $75 \mathrm{~cm} \times 15 \mathrm{~cm}$ & 951 & 856 & 25 & 21400 & 1201.31 & 20198.69 & 0 \\
\hline $60 \mathrm{~cm} \times 15 \mathrm{~cm}$ & 1260 & 1134 & 25 & 28350 & 1501.69 & 26848.31 & 2213.7 \\
\hline $75 \mathrm{~cm} \times 10 \mathrm{~cm}$ & 1258 & 1132 & 25 & 28300 & 1801.95 & 26498.05 & $\mathrm{D}$ \\
\hline $50 \mathrm{~cm} \times 15 \mathrm{~cm}$ & 1323 & 1190 & 25 & 29750 & 1802.00 & 27948.00 & 366.18 \\
\hline $60 \mathrm{~cm} \times 10 \mathrm{~cm}$ & 1918 & 1726 & 25 & 43150 & 2252.55 & 40897.45 & 2874.14 \\
\hline $50 \mathrm{~cm} \times 10 \mathrm{~cm}$ & 2140 & 1910 & 25 & 47750 & 2703.00 & 45047.00 & 921.20 \\
\hline $75 \mathrm{~cm} X 5 \mathrm{~cm}$ & 1895 & 1705 & 25 & 42625 & 3603.99 & 39021.01 & $\mathrm{D}$ \\
\hline $60 \mathrm{~cm} \times 5 \mathrm{~cm}$ & 2433 & 2190 & 25 & 54750 & 4505.00 & 50245.00 & 288.46 \\
\hline $50 \mathrm{~cm} \times 5 \mathrm{~cm}$ & 2474 & 2227 & 25 & 55675 & 5406.00 & 50269.00 & 2.66 \\
\hline
\end{tabular}

Adj. yield= adjusted yield, ETB $=$ Ethiopian birr , $\mathrm{ETB}^{-1}=$ Ethiopian birr per kilogram, MRR= Marginal Rate Return

\section{Conclusion and recommendations}

Planting density is one of the main factors that have an important role on growth, yield and quality of ground nut. It is important to accommodate the most appropriate number of plants per unit area of land to obtain better yield.

The highest total number of pods per plant (21.36) was obtained from variety manipinter. With regards to spacing, the highest number of pods per plant $(25.00$ and 22.45$)$ was obtained from $75 \mathrm{cmx} 10 \mathrm{~cm}$ followed by $75 \mathrm{~cm} \times 15 \mathrm{~cm}$ respectively. The highest grain yield $\left(2105 \mathrm{~kg} \mathrm{ha}^{-1}\right)$ was obtained for variety mainipinter while the lowest grain yield (1373 $\mathrm{kg} \mathrm{ha}^{-1}$ ) was obtained for variety 'sartu'. Regarding to spacing, the highest grain yield (2474 and $2433 \mathrm{~kg} \mathrm{ha}^{-1}$ ) was obtained from $50 \mathrm{~cm} \times 5 \mathrm{~cm}$ and $60 \mathrm{~cm} \times 5 \mathrm{~cm}$, respectively. Generally, decrease in spacing reduced the number of pods plant ${ }^{-1}$ of ground nut, but the additional plants $\mathrm{m}^{-2}$ more than compensated for the reduction, resulting in higher grain yield. Economic analysis of different spacing revealed that gave different economic return as compared to control $(60 \mathrm{~cm} \times 10 \mathrm{~cm})$. The highest net benefit $\left(50269.00 \mathrm{ETB}^{-1}\right) \mathrm{was}^{-1}$ recorded from $50 \mathrm{~cm} \times 5 \mathrm{~cm}$ spacing followed by $60 \mathrm{~cm} \times 5 \mathrm{~cm}$ spacing $\left(50245.00 \mathrm{ETB} \mathrm{ha}^{-1}\right.$. Therefore spacing of $50 \mathrm{~cm} \times 5 \mathrm{~cm}$ and $60 \mathrm{~cm} \times 5 \mathrm{~cm}$ was optimum plant population density for production of ground nut in Kelem Wollega zone of western Ethiopia.

\section{REFERENCES}

A.Y. Kamara, F. Ekeleme, J.D. Kwari, L.O. Omoigui and D. Chikoye, 2011 Phosphorus effects on growth and yield of groundnut varieties in the tropical savannas of northeast Nigeria. Journal of Tropical Agriculture 49 (1-2): $25-30$

Abdullah, T., Rahmianna, A.A., Hardaningsih, S. and Rozi, F. 2007. Increasing groundnut yield on dry land Alfisols in Indonesia. Journal of Semi-Arid Tropics Agricultural Research, 5(1): 84 - 96.

Ahmad N, Mohammad R, Ulas K . 2007. Evaluation of different varieties, seed rates and row spacing of groundnut, planted under agro-ecological conditions of Malakand Division. Journal of Inter academia 9(4):178-183.

Ali Y., Ahsanul Hag M., Tahir G.R., Ahmad N.,1999. Effect of Inter and Intra Row Spacing on the Yield and Yield Components of Chickpea. Pak. Journal of Biological Science, 2 (2): 305-307

Arrison Kwame Dapaah, Ibrahim Mohammed and Richard Tuyee Awuah,2014 Phenological Development and Yield of Three Groundnut Varieties as Influenced by Plant Density in a Forest-savanna Transition Zone International Agricultural Research 9 (2): 87-98.

Journal

of

Bihter Onat, Halil Bakal , Leyla Gulluoglu , Halis Arioglu 2017. The effects of row spacing and plant density on yield and yield components of peanut grown as a double crop in mediterranean environment in turkey. Turk journal of field crops 22(1), 71-80

CIMMYT (International Maize and wheat improvement center) 1198.From agronomic data to farmer recommendations. Economics training manual completely revised edition, MECECO.

CSA (Central Statistical Agency), 2017. The federal democratic republic of Ethiopia central statistical agency, Agricultural sample survey. Volume I, Report on area and production of major crops (private peasant holdings, meher season), Addis Ababa, Ethiopia.

FAOSTAT. 2010. Groundnut world production. http://www.faostat.fao.org.

Gbèhounou, G. and Adengo, E., 2003. From a crop rotation experiment at Akron. Effect of citric acid on aflatoxin degradation and on functional and textural. Food Research International, Volume 42, Issue 8

Hussain I., Ayyaz Khan M., Ahmad K., 2003. Effect of row spacing on grain yield and the yield components of wheat (Triticum aestivum L.). Pak. Journal of Agronomy 2 (3): 153-159. 
Kiniry, J.R., Simpson, C.E., Schubert, A.M. and Reed, J.D. 2005. Peanut leaf area index, light interception, radiation use efficiency, and harvest index at three sites in Texas. Field Crop Research 91:297-306

Konlan, S., SARKODIE-ADDO, J., Asare, E. and Kombiok M. J. 2013. Groundnut (Arachis hypogaea L.) varietal response to spacing in the Guinea savanna agro-ecological zone of Ghana: Growth and yield African Journal of Agricultural Research 8(22), 2769-2777

Lee HC, Berry MP, De Toledo VC, Deffune G, Haymes R, Lopez RJ, Morrish CJ, Rodigues R, Scofield AM, Watt TA, Wu BZ (1994). Nonchemical weed management in major UK arable crops. In: Arable farming under CAP reform. Clarke J, Lane A, Mitchel A, Ryans P (Eds), Aspects of applied Biology. 40:317-324.

Naeem Ahmad, Mohammad Rahim and Ulas Khan, 2007. Evalution of different varieties, Seed Rates and Row Spacing of groundnut, planted under Agro-eclogical Conditions of Malakand Division. Journal of Agronomy, 6: 385-387

Norden AJ, Lispcomb RW (1974). Influence of plant growth habit on peanut production in narrow rows. Crop Science. 14:454-457.

Pande, N., Saxena, J. and Pandey, H. 2003. Natural occurrence of mycotoxins in some cereals. Mycoses, 33:126128

Pereira L.R., Bainer A.C., Vellase J.A.R., 1988. Santos H.P., Row spacing and seed rate in two wheat cultivars. Pesquisa Agropecvaria Brasileria, 23: 1143-1149

Upadhyaya, H.D., Reddy, L.J., Gowda, C.L. and Singh, S. 2006. Identification of diverse groundnut germplasm: Sources of early maturity in a core collection. Field Crops Research, 97: 261-271.

Virender S, Kandhola SS . 2007. Productivity of semi-spreading and bunch type varieties of groundnut as influenced by sowing dates. J.SAT Agric. Res. 5(1).

Virk AS, Kaul JN, Bhangoo BS, Singh A . 2005. Influence of planting techniques and plant population on Biology and pod productivity of summer groundnut varieties. Research Crops 6(1):173-174. 